\title{
Review: Climate Finance readiness of the animal protein sector: overview of experience in linking the sector to Climate Finance, and options to address bottlenecks
}

\author{
J. Massé ${ }^{1 \dagger} \odot$, P. J. Gerber 2,3, C. Halpern ${ }^{2,3}$ and T. Baedeker ${ }^{1}$ \\ ${ }^{1}$ World Bank Group, 1818 H Street NW, Washington, DC 20433, USA; ${ }^{2}$ World Bank Group, Radnička cesta 80, 10000 Zagreb, Croatia; ${ }^{3}$ Wageningen University \& \\ Research, 6708 PB Wageningen, Netherlands
}

(Received 15 February 2020; Accepted 9 July 2020; First published online 19 August 2020)

\begin{abstract}
Despite the importance of the role of Climate Finance to comply with the United Nations Framework Convention on Climate Change $1.5^{\circ} \mathrm{C}$ objective, there is no consensus on the definition of Climate Finance and the estimated assessment of its aggregated flows and effects remains challenging. Despite being a major emitter and having a significant and cost-effective mitigation potential, the livestock sector has so far only received a marginal share of Climate Finance. As demand for animal protein products continues to increase (68\% between 2010 and 2050), there is a compelling case for channeling more Climate Finance investments into the sector to incentivize greenhouse gas emissions reduction at scale. Bottlenecks in linking the livestock sector to Climate Finance include the insufficient capacity to assess the cost-benefit of projects, high upfront cost and risk perception of investors, the informality of the sector, non-existence of Climate Finance instruments dedicated to the livestock sector and lack of cost-efficient Monitoring, Reporting and Verification systems. Nevertheless, recent developments provide avenues to increase the access of the animal protein sector to Climate Finance.
\end{abstract}

Keywords: livestock sector, greenhouse gas mitigation, low-emission practices, land-use change, climate change

\section{Implications}

The animal protein sector is a significant greenhouse gas emissions contributor, and despite having a vast potential for mitigation so far has received very minor financial flows dedicated to greenhouse gas emissions mitigation compared to other sectors of the economy. This review focuses on framing Climate Finance and analyzing the barriers and opportunities to channel more Climate Finance flows into the animal protein sector.

\section{Introduction}

Livestock supply chains are estimated to emit $7.1 \mathrm{Gt}$ CO2-eq. per year or about $14.5 \%$ of global anthropic greenhouse gas (GHG) emissions (Gerber et al., 2013). Population growth and growing demand for protein-rich foods, especially in the developing world, intensify pressure on the environment due to livestock. Animal-based protein consumption is expected to increase by $68 \%$ between 2010 and 2050 . Maintaining the current productions methods would induce

\footnotetext{
† E-mail: jmasse1@worldbank.org
}

a similar increase in GHG emissions and land-use change (Searchinger et al., 2019). The implementation of mitigation practices within the livestock supply chains is imperative, but the sector has so far not benefited from the increasing flows of Climate Finance. The use of Climate Finance flows will be essential to fund the transition toward a low-emission sector. This is not only to meet the required upfront costs but also to face the additional production costs implied by a transformation of the practices in the sector, and the monitoring or their effects.

This review describes the framework of Climate Finance, then addresses the principal barriers limiting access of the animal protein sector to Climate Finance. It finally informs on recent initiatives and developments that address these barriers and open the way toward increasing the readiness of the sector to access Climate Finance.

Framing Climate Finance: definition and key concepts Definitions and architecture of Climate Finance Implementing mitigation strategies requires the use of several complementary policies and mechanisms such as 
regulatory measures and international commitments. Climate Finance is one tool that can be used to reach GHG emissions reduction goals. The definition of Climate Finance is still subject to discussion. United Nations Framework Convention on Climate Change (UNFCCC) frames it as ' . . local, national or transnational financing - drawn from public, private and alternative sources of financing that seeks to support mitigation and adaptation actions that will address climate change' (UNFCCC). This definition encapsulates all financial flows addressing climate change mitigation and adaptation, from any available sources, public or private. The Cancun Agreement narrows down the definition by including the concepts of 'new and additional' funding (UNFCCC, 2010). These new criteria are also a source of debate, as the financial baseline modalities and their monitoring and evaluation still need to be defined (Streck, 2011). Climate Policy Initiative (CPI) defines it as the total costs of investments into projects dedicated to mitigation or adaptation, combined with the public expenditures needed to enable the investments, such as technical assistance or monitoring capacities. However, CPI's definition excludes revenue streams derived from projects implementation, such as carbon credits (Falconer and Stadelmann, 2014). The Overseas Development Institute and Heinrich Böll Foundation Climate Funds Update, which attempts to track the flows of Climate Finance, recognize that no internationally acknowledged definition exists (Watson and Schalatek, 2019). Warren (2019) intends to fill the existing gap for a consensual definition and characterizes it as 'a sub-set of green finance and refers to investments specifically in climate change mitigation and adaptation activities, which primarily involve public finance and the leveraging of private finance', whereas green finance, although broader, has a greater focus on private investments.

The definition used in this paper is the one of UNFCCC that encompasses all the financial flows dedicated to climate mitigation or adaptation.

Marke and Sylvester (2018) count more than 99 Climate Finance funds and initiatives. Climate Finance architecture encompasses a variety of public actors: governments, multilateral aid agencies, development finance institutions and climate funds. Private actors are mostly corporations; however, commercial financial institutions have recently increased their role (Buchner et al., 2019). Financial instruments dedicated to Climate Finance are likewise very diverse, including grants, concessional and non-concessional loans, equities, carbon credits and virtually any alternative financing oriented toward mitigation and adaptation.

The broad and multiple definitions of Climate Finance and the variety of instruments and delivery channels make it difficult to aggregate and measure its flows and effects. Furthermore, because there is no internationally agreed methodology to track the private Climate Finance flows, it remains a challenge to evaluate the specificities of private investments related to Climate Finance (Stadelmann et al., 2013). However, the diversity of instruments also multiplies the options and possibilities for recipient projects or countries to access Climate Finance (Watson and Schalatek, 2019). The choice of instruments depends on the profitability of the project and its economic viability. Grants and concessional loans are preferred for projects that cannot be selfsustainable, while carbon credits may be used for already viable projects for which the cost of reducing GHG emissions can be covered by the additional revenues of carbon credits.

Monitoring, Reporting and Verification of greenhouse gas emissions, a cornerstone concept within Climate Finance Monitoring, Reporting and Verification (MRV) is a concept increasingly connected to Climate Finance. The need for financing mitigation activities is paired with a need for greater transparency and accountability. By addressing 'measurable, reportable, and verifiable nationally appropriate mitigation commitments or actions (...) supported and enabled by technology, financing and capacity-building, in a measurable, reportable and verifiable manner', the Bali Action Plan in 2007 acknowledged the need for MRV in the context of GHG emissions mitigation (UNFCCC, 2008). The three steps of MRV, both separate and interconnected, are essential to ensure a clear assessment of GHG sources and emission levels, and a consistent impact measurement of financed mitigation strategies. Having MRV systems in place progressively became a pre-requisite to access Climate Finance funds (Ballesteros et al., 2010). Monitoring, Reporting and Verification systems include the following processes (Singh et al., 2016): monitoring or measuring may relate to a physical or estimated measure of the reduction of GHG emissions. Reporting involves the compilation and standardization of gathered or calculated data to make it comparable and available to other parties. The last step, verification, entails a review of the report to assess its accuracy and reliability.

The goals and characteristics of MRV systems depend on the level at which they operate (Table 1) (Ninomiya, 2012). The UNFCCC framework for the MRV of GHG emissions is typically relevant at the national level. While more affluent countries are consistently reporting their emissions, comprehensive emission reporting remains a challenge in low- and middle-income countries, due to gaps in data, limited technical capacities, weak institutional framework and low recognition of the relevance of GHG emissions MRV (Umemiya et al., 2015).

At a policy level, although climate change mitigation policies usually have quantified objectives, the MRV processes can be unclear. Monitoring, Reporting and Verification used at policy level is mostly used in the framework of the Nationally Appropriate Mitigation Actions (NAMA) - a set of practices that reduce GHG emissions in low-income countries and designed as part of a governmental initiative (UNFCCC, 2015). Developing parties are expected to measure the reduction of GHG emissions against a business-as-usual baseline assessed during the design phase of the program. However, modalities of the verification of the GHG emissions reduction have not been decided yet, including how and who will perform this step (Umemiya et al., 2015). Furthermore, the same 
Table 1 Goals and characteristics of Monitoring, Reporting and Verification (MRV) processes by implementation level (Singh et al., 2016)

\begin{tabular}{|c|c|c|c|c|}
\hline & $\begin{array}{l}\text { MRV of GHG emissions at } \\
\text { the national level }\end{array}$ & $\begin{array}{l}\text { MRV of GHG reduction } \\
\text { by policy }\end{array}$ & $\begin{array}{l}\text { MRV of GHG reduction at the } \\
\text { project level for crediting }\end{array}$ & $\begin{array}{l}\text { MRV of GHG emissions } \\
\text { at the organization level }\end{array}$ \\
\hline Aim & $\begin{array}{l}\text { Determination of GHG } \\
\text { emissions } \\
\text { at the national level and } \\
\text { compliance assessment } \\
\text { within the UNFCCC } \\
\text { Framework }\end{array}$ & $\begin{array}{l}\text { Quantitative evaluation of } \\
\text { policy/action }\end{array}$ & $\begin{array}{l}\text { Crediting and certification of the } \\
\text { amount of GHG reductions by } \\
\text { individual project under GHG } \\
\text { scheme }\end{array}$ & $\begin{array}{l}\text { Determination of GHG } \\
\text { emissions under the } \\
\text { GHG scheme }\end{array}$ \\
\hline \multirow[t]{3}{*}{ Characteristics } & $\begin{array}{l}\text { Technically matured and } \\
\text { primarily used in developed } \\
\text { countries }\end{array}$ & Undeveloped MRV & Very high required level of accuracy & Variable level of accuracy \\
\hline & $\begin{array}{l}\text { Not well established in } \\
\text { developing counties }\end{array}$ & $\begin{array}{l}\text { Required level of accuracy } \\
\text { unknown }\end{array}$ & $\begin{array}{l}\text { Growing number of technically well } \\
\text { matured and sophisticated MRV }\end{array}$ & $\begin{array}{l}\text { Sufficient knowledge and } \\
\text { experiences accumulated } \\
\text { in developed countries }\end{array}$ \\
\hline & & $\begin{array}{l}\text { Important regarding the } \\
\text { effectiveness of } \\
\text { international climate } \\
\text { regime }\end{array}$ & $\begin{array}{l}\text { Technical difficulties: baseline setting, } \\
\text { additionality }\end{array}$ & Relatively simple \\
\hline \multirow[t]{3}{*}{ Examples } & National GHG Inventories & $\begin{array}{l}\text { Nationally Appropriate } \\
\text { Mitigation Actions }\end{array}$ & Clean Development Mechanism & The Climate Registry \\
\hline & $\begin{array}{l}\text { Intended Nationally } \\
\text { Determined Contributions }\end{array}$ & & Verified Carbon Standard & $\begin{array}{l}\text { Regulatory or voluntary } \\
\text { carbon footprint } \\
\text { reporting }\end{array}$ \\
\hline & & & Gold standard & \\
\hline
\end{tabular}

GHG = greenhouse gas; UNFCCC = United Nations Framework Convention on Climate Change.

challenges related to MRV in developing countries described earlier would also be expected to apply here.

Monitoring, Reporting and Verification of GHG reduction for crediting has the highest level of accuracy, and a large number of methodologies have been developed. Monitoring, Reporting and Verification is critical in the development of carbon credit schemes, as the three-step process allows the entity implementing the project to claim carbon credits. Verification is usually performed by a third-party agency, ensuring the transparency and reliability of the GHG emissions reductions reported. The MRV process is an essential element in the design of emission reduction projects. The MRV methodology includes the scope of its applicability, the baseline scenario, the project's leakage and emissions. This ensures that the offsets are, additional, measurable and verifiable (Hamrick and Gallant, 2018). Finally, the MRV of GHG emissions at the organization level refers to regulatory or voluntary carbon footprint reporting. The process is well implemented in developed countries with the development of corporate sustainability reports. However, the level of accuracy is disparate as there are no standardized tools and methodologies for carbon footprint evaluation (Siew, 2015).

\section{Climate Finance readiness}

Climate Finance readiness is a widely used term in the Climate Finance realm. The Green Climate Fund (GCF), which developed the GCF readiness program, defines it as 'a country's capacity to (1) plan for, (2) access, and (3) deliver Climate Finance, as well as (4) monitor and report on expenditures.' Readiness, in this case, embodies the conditions that need to be in place in a given country in order to access GCF funds. It includes requirements related to the country's capacity to access Climate Finance, to allocate and distribute the funds and finally to report on the impact of the program (GCF, 2015). The United Nations Development Program defines being ready for Climate Finance as 'the capacities of countries to plan for, access, deliver, and monitor and report on Climate Finance, both international and domestic, in ways that are catalytic and fully integrated with national development priorities and achievement of the Millennium Development Goals (MDGs)' (Vandeweerd et al., 2015). Overseas Development Institute and the Africa Climate Finance Hub emphasize that evaluating the readiness of a country to access Climate Finance should be relative, taking into account the characteristics of each country, responsive to the needs and challenges of the particular country, and reasonable, having identified the country's specific challenges (Nakhooda et al., 2012). Readiness has become an essential element of Climate Finance, and several readiness programs have developed, such as the GCF Readiness Program, the Readiness and Preparatory Support Initiative, managed by $\mathrm{KfW}$ and the Deutsche Gesellschaft für Internationale Zusammenarbeit $\mathrm{GmbH}$, and the Forest Carbon Partnership Facility's Readiness Fund. Readiness has the potential to increase the efficiency of Climate Finance received by developing countries. However, as with Climate Finance, there is no consensus definition and measure of a country's Climate Finance readiness. 


\section{Flows of Climate Finance}

The Intergovernmental Panel on Climate Change estimates the need for Climate Finance to be 2.4 trillion annually between 2016 and 2035, for the energy system only, to keep global warming under $1.5^{\circ} \mathrm{C}$ (Masson-Delmotte et al., 2018). The flows of Climate Finance are estimated to $\$ 546$ billion for 2018 (Climate Policy Initiative, 2019), while UNFCCC estimates it to $\$ 681$ billion for 2016 (UNFCCC, 2019). This gap illustrates the lack of consensus around the definition of the flows of Climate Finance. The report 'Global Landscape of Climate Finance' by CPI represents the most comprehensive report for Climate Finance flows, although acknowledging some data gaps within private flows and domestic public finance.

Climate Policy Initiative estimates that private finance represented $56 \%$ of the total Climate Finance flows for the years 2017/2018, on average. Among the public actors, development finance institutions represented $86 \%$ of the flows. In the private sector, corporations are the major actors $(56 \%)$, but commercial finance institutions and households represent an increasing part of these flows. Debt is the most used instrument $(66 \%)$, followed by equity $(29 \%)$ and grants $(5 \%)$. Geographically, developing countries are the leading destination of the flows $(61 \%)$, with a strong focus on East Asia ( $41 \%$ of all flows). Mitigation programs represent $93 \%$ of all flows. The sectors of low-carbon transportation, renewable energy and energy efficiency represented US\$ 186 billion or $87 \%$ of the public mitigation flows in 2017 to 2018 (Figure 1). This trend suggests that Climate Finance is still focusing on the 'low-hanging fruits' that are energy and transportation - agriculture, where mitigation is more complex to implement, represents only $5 \%$ of the mitigation flows (Figure 1). Nevertheless, mitigation flows dedicated to agriculture have almost risen threefold, from $\$ 4$ billion in 2015 to 2016 to $\$ 11$ billion in 2017 to 2018.

Agriculture, forestry land-use and natural resource management represent an important part, at almost a quarter, of the public adaptation finance flows (Figure 2).

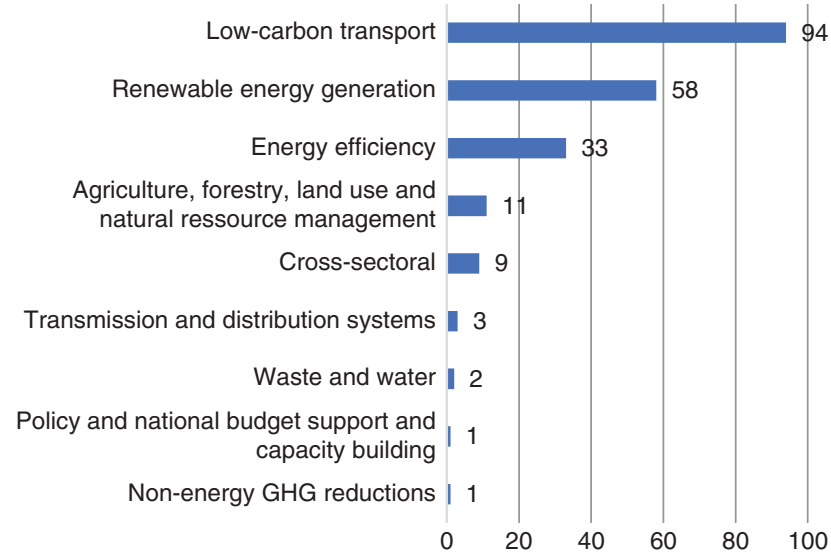

Figure 1 (colour online) Average annual public mitigation finance 2017 to 2018 in billion US\$. Source: Buchner et al. (2019).

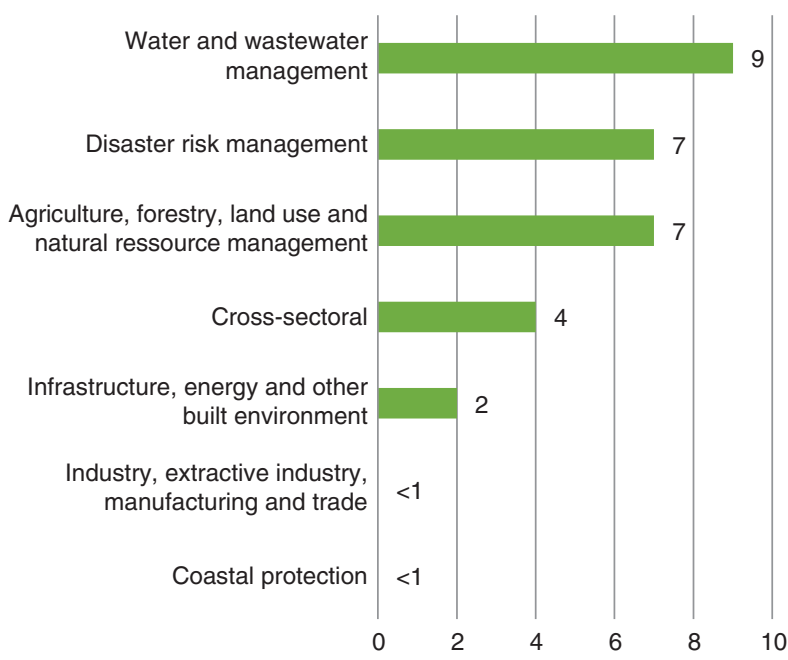

Figure 2 (colour online) Average annual public adaptation finance 2017 to 2018 in billion US\$. Source: Buchner et al. (2019).

The flows of finance from carbon credits are challenging to evaluate and aggregate because of the disparities of standards. In 2018, the Clean Development Mechanism (CDM) and the Joint Implementation (JI) issued 2.8 Gigatons $\mathrm{CO}_{2}$ equivalent. However, the volume of carbon credits emissions is decreasing since 2013 , due to the uncertainty around the future of these two mechanisms and the low price of carbon credits (World Bank, 2019b).

The voluntary market represents a much smaller part of Climate Finance, with \$191.3 million bought in 2016 to offset 63.4 MtCO2e. The most two traded offset categories were renewables and forestry and land use, representing 64\% of the total carbon offset traded that year (Hamrick and Gallant, 2017).

\section{Channeling Climate Finance into the animal protein sector}

Climate Finance flows are not adapted to the scale of the sector's greenhouse gas emissions

Although the animal protein sector is responsible for $14.5 \%$ of the global enteric GHG emissions and has a mitigation potential of 30\% (Gerber et al., 2013), the sector remains mostly absent as a recipient of mitigation Climate Finance flows. As previously described, agriculture accounts for only a small part of the mitigation effort.

The environmental challenges that need to be overcome are expected to increase as the global population is expected to grow to 9.7 billion by 2050, or approximately $26 \%$ (United Nations, 2019). The demand for animal protein products is expected to increase by $68 \%$ between 2010 and 2050 (Searchinger et al., 2019), driven by the growth of global population, urbanization and incomes (FAO, 2018). Alexandratos and Bruinsma (2012) estimate that global milk production will grow by $62 \%$ and meat production by almost $75 \%$ by 2050 compared to the 2005 levels. 
The pressure on the environment from livestock is considerable. Africa's consumption of animal protein products is expected to increase by $80 \%$ between 2010 and 2030 . During this period, the total beef consumption is expected to increase by $125 \%$, eggs by $77 \%$, milk by $46 \%$ and poultry by $60 \%$ (World Economic Forum, 2019). This 'livestock revolution' is caused both by steady population growth, increasing the number of consumers, and by socio-economic factors such as income growth and urbanization that tends to increase the amount of protein consumed per capita. The African population is expected to grow from 1.58 billion in 2019 to 2.01 billion in 2030, or by 27\% (United Nations, 2019), with 1.4 billion living in Sub-Saharan Africa (United Nations, 2019). Per capita income could grow by as much as $50 \%$ during the 2015 to 2050 period (International Monetary Fund, 2015). As a result, between 2005/07 and 2030, meat and milk consumption are projected to grow by $2.8 \%$ and $2.3 \%$ per year across the continent (World Bank, 2014). Cattle and goats on the continent were emitting 7.8 million tons of $\mathrm{CH} 4$ in 2000 , and these emissions are expected to increase to 11.1 million tons by 2030 .

If sectors and emissions are projected to be particularly strong in Africa, they will also grow in other regions. Globally, if we witness a continuous linear relationship between livestock population and methane emissions, global methane emissions are likely to increase by $30 \%$ by 2030 (Herrero et al., 2008). De Sy et al. (2015) quantified the relationship between deforestation and pasture expansion in seven Latin American countries. This study reveals that grazing was responsible for $71 \%$ of forest clearing occurring between 1990 and 2005 in Argentina, Bolivia, Brazil, Colombia, Paraguay, Peru and Venezuela. About $9.2 \%$ of total livestock GHG emissions are credited to land-use change - where pasture expansion is responsible for $6 \%$ and feed crop for 3.2\% (Gerber et al., 2013). Cattle ranching is reckoned to be the principal cause of deforestation of the Amazon, but the cultivation of soy is often occurring on lands formerly used as pastures, hence indirectly intensifying the conversion of forest to pastures in other areas (Barona et al., 2010).

Several mechanisms at distinct levels of the supply chain can be put in place to mitigate deforestation and GHG emissions caused by livestock. Mitigation practices such as reduction and reversal of deforestation rates related to feed and pasture production, accumulation of above and below ground carbon in pastures, reduction of direct emissions from enteric fermentation and manure management, feeding methane inhibitor additive to ruminants, generating renewable energy and increasing energy efficiency along supply chains (Gerber et al., 2013) and shifting human diets toward less emission-intensive sources of protein and micronutrients will effectively reduce GHG emissions (Herrero et al., 2009).

\section{Barriers to overcome to access Climate Finance}

Even though several avenues toward reducing the environmental impact of livestock are well known, several barriers limit the adoption of such practices. Increasing the readiness of the livestock sector to access Climate Finance would require addressing these issues.

A first barrier relates to the financial costs to implement such strategies (Dulal and Brodnig, 2010; Avetisyan et al., 2011; Sadler, 2016). Although some mitigation practices, especially related to the intensification of the sector, can translate, in the long run, into benefits, the upfront cost remains high to ensure the broad adoption of such measures. Furthermore, while the technical aspects of the mitigation processes are well known, few studies provide cost-benefit analysis (Henderson et al., 2018). Because of this uncertainty about the cost-efficiency of mitigation strategies, there is no comparison possible with low-carbon investments in other sectors. As long as this comparison will not be feasible, Climate Finance flows will be directed toward other sectors such as clean energy and clean transportation. Even in cases where financial incentives are offered, such as payments for environmental services programs or concessional financing, the long-term adoption of practices and the permanence of reduction of GHG emissions depend on the profitability of such projects. Because the financial returns are still unknown, financing options, particularly Climate Finance flows, are not sufficiently channeled toward the livestock sector. Risks and opportunities for agricultural investments are not well understood by investors, resulting in investment channels that are not adapted to the sector (Sadler, 2016). Investors are still reticent to support mitigation activities in the sector, favoring clean transportation and energy for which the financial viability of transformation has been proven. Because of this lack of interest, Climate Finance has no tailor-made products adapted to the transformation of the animal protein toward a low-carbon sector.

The informality and lack of cohesion of the animal protein sector in low- and middle-income countries remains an obstacle to access to Climate Finance (Dulal and Brodnig, 2010). More than 380 million smallholder farming households are producing more than half of the calories produced in the world (FAO, 2014). It remains challenging for Climate Finance flows to reach these farmers, to scale up mitigation programs and to achieve economies of scale.

Furthermore, farmers often lack the technical capacities to implement mitigation strategies (Mottet et al., 2017; Dulal and Brodnig, 2010). The technical assistance should be a core component of mitigation programs, along with education about climate change, with the risk of complexifying and increasing the cost of implementation. Mottet et al. (2017) also point out the risks livestock producers face when changing their practices for the adoption of new production systems that lower emissions, and the need to address such risks when designing interventions. In addition to technical barriers, smallholder farmers sometimes engage in livestock production for non-commercial reasons, such as household consumption or cultural values (Mtimet and Dube, 2018). Greenhouse gas mitigation programs need to take into consideration socio-cultural barriers and means to overcome them to increase the readiness of the sector to access Climate Finance. 
Finally, MRV methodologies are not yet adapted to the needs of the sector (Wilkes et al., 2017). Among the nine existing MRV methods developed in the framework of UNFCCC by the CDM and the Jl, seven are related to manure management, one to productivity increase and one to enteric fermentation (Joint Implementation, 2020; Clean Development Mechanism, 2019). Seven voluntary market standards were also analyzed (American Carbon Registry, California Air Resources Board, Climate Action Reserve, Climate Forward, Gold Standard, Plan Vivo and Verified Carbon Standard). Due to these markets, $10 \mathrm{MRV}$ methodologies for the livestock sectors were developed, with again a strong focus on manure management (4 methodologies), followed by land use (2 methodologies), 2 other methodologies were dedicated to integrated GHG management and only 1 to enteric fermentation. The preponderance of methodologies related to manure management is disconnected from the sources of GHG emissions of the livestock sector. Manure management is only responsible for $9.5 \%$ of the sector's GHG emissions (Gerber et al., 2013). Furthermore, reducing the GHG emissions from the sector at scale will require the implementation of several mitigation practices simultaneously, such as intensification and land-use change. This shortfall in methodologies still needs to be addressed, as being able to measure GHG emissions reduction is a precondition to enable Climate Finance flows.

\section{The way forward: drawing lessons from initiatives that enable the readiness of the livestock sector}

Recent developments in agriculture and finance prove that a viable pathway exists toward financing mitigation activities. This section intends to show that a more Climate Finance suited understanding of the GHG emissions in the livestock sector has begun, and that solutions have started to be implemented. This section is not exhaustive but describes the existing momentum toward a greener animal protein sector and the increasing readiness of livestock value chains to access Climate Finance.

\section{The rise of public awareness fosters the engagement of the private sector}

The South American beef value chain and its impact on deforestation in the Amazon were recently in the media spotlight, bringing public awareness to environmental challenges related to the livestock sector. Consequently, corporations throughout the Brazilian beef value chain are taking actions to avoid association with deforestation. The meat processing market is highly concentrated in Brazil. The top three publicly listed companies, JBS, Minerva Global Food and Marfrig, represent $70 \%$ of the market share of the sector (Galaz et al., 2018). Marfrig and Minerva publish sustainability reports in which they describe their commitments to avoid sourcing animals linked to illegal deforestation (Marfrig, 2018; Minerva, 2016). However, Minerva has not mentioned its actions against deforestation in its last two sustainability reports. In addition to its sustainability commitments,
Marfrig sold a US\$ 500 million transition bond in July 2019 to halt deforestation induced by its suppliers in the Amazon biome. The bond will finance the investment needed to develop programs to stop deforestation caused by the whole animal value chain, from their direct suppliers (fattening farms) to the calve producers. The program will be implemented in collaboration with The Sustainable Trade Initiative (IDH) (IDH, 2019).

Some retailers, such as Walmart, Carrefour and Cencosud committed to source meat products only from processors who are not linked to illegal deforestation (Walmart Inc., 2019, Carrefour Foundation, 2018; Cencosud Brazil, 2018). Walmart has developed a Brazil Beef Monitoring System, which allows for tracking their meat's origin and ensures it is not involved in illegal deforestation (Walmart Inc., 2019). However, there is little information available about monitoring of indirect suppliers.

Among other international companies sourcing commodities in Brazil, Cargill has committed US\$ 30 million in June 2019 to finance ideas that can halt deforestation in the Amazon and Cerrado biomes (Financial Times, 13 June 2019). McDonald's has developed partnerships with local companies, Proforest and Agrotool, to improve the tracking of beef suppliers and determine their impact on deforestation (McDonald's, 2019).

Sectoral platforms related to the animal protein value chains are developing worldwide, facilitating the dialogue among the different actors of the value chain. The Global Roundtable for Sustainable Beef is very active in South America. Four South American countries have local roundtables: Brazil, Colombia, Argentina and Paraguay (GRSB, 2018). A Joint Working Group on Forest was created in 2012 to offer an open forum for the relevant stakeholders to advance solutions and challenges related to deforestation-free cattle ranching. Around 80 members are part of the discussion, and the central takeaway of their last consultation in 2018 was the importance of monitoring indirect cattle suppliers. The group acts as an advisor for the Consumers Good Forum on questions related to beef and deforestation (GRSB, 2018).

In the dairy sector, the Global Dairy Platform created the Dairy Sustainable Framework to provide a set of best practices to reach sustainability goals within the sector. It also aims at providing a framework to monitor the implementation and impacts on environmental sustainability (Dairy Sustainability Framework).

\section{Engagement of the public sector}

The public sector's involvement is also growing, notably with the development of Nationally Determined Contributions (NDCs) and NAMAs in Latin America. For example, Brazil Carbon Trust is collaborating in the development Brazil's NAMA related to livestock, with the ambitious objectives of cutting the $\mathrm{CO}_{2}$ emissions per hectare by $50 \%$ and reducing the emissions intensity of beef by $90 \%$. To reach this goal, Carbon Trust is investing in the development of MRV methodologies that capture data on land use, animals, pasture, inputs and outputs. Guatemala's livestock NAMA 
intends to contribute $12 \%$ of the country's NDC targets. In Uruguay, through improvement in grassland and animal productivity, a NAMA aims at decreasing the nitrous oxide and methane emissions by $40 \%$ by 2030 . A sophisticated tracking system that informs on location, diet quality, milk production and BW will be used to support the monitoring of emissions reductions (White, 2018).

In 2019, the World Bank, in collaboration with the Food and Agriculture Organization of the United Nations, launched the Investing in Sustainable Livestock (ISL) guide. This web-based guide is a practical tool and information resource for livestock managers to promote environmental - and broader - sustainability. It allows users to identify the main issues related to their operations and to access the resources to address them. It aims at decomplexifying issues linked to investing in the livestock sector and addressing trade-offs. As the investment in the animal protein sector is expected to grow in support of an increasing demand over the coming decades, the ISL guide and tool will be a support to investors to further the implementation of environmentally sound projects (World Bank, 2019a).

\section{Innovative financial mechanisms can address financial barriers}

Projects that require high expenses in technical assistance and monitoring, additionally to inherent risks, struggle to attract private investors as the risk-return profile is too weak (Rode et al., 2019). This is the case of projects related to reducing deforestation and GHG emissions induced by the livestock sector. Still, the development of new financial mechanisms, such as blended finance involving several types of investors and donors, can be vital in financing the transition toward a low-emission livestock sector.

The goal of blended finance is to unlock private investments in typically less-desirable projects by using traditional development donors and concessionary investors, such as multilateral organizations, foundations and development banks, to de-risk the investments. Through this combination of several actors, development projects can attract commercial investors who do not usually participate in such projects (The Blended Finance Task Force, 2018). In practice, this means that traditional development investors will offer a layer of insurance to commercial investors. This can be done by organizing and paying for the technical assistance needed at the inception of a project, which can considerably lower its profitability, or by absorbing the first losses of an investment and offering a better risk profile to commercial investors, or even by providing guarantees on investments (The Global Impact Investing Network, 2018).

These mechanisms could be adapted to investing in the intensification of livestock production and limiting deforestation, land degradation and methane emissions. Indeed, these projects require high entry costs related to technical assistance and monitoring. This is often perceived as risky for commercial investors but can be profitable in the long run. Using blended finance allows leveraging on what each investor does best: traditional development finance to target investments with higher environmental and social impact and organizing the technical assistance and monitoring, and commercial investors to assess the economic sustainability of a project in the long run.

\section{Conclusion}

Despite its status as a major GHG emitter and the presence of significant cost-effective mitigation potential, the animal sector has only received a marginal share of Climate Finance so far. The main bottlenecks explaining this situation include the risk perception of investors, the informality of the animal protein sector, the challenges in designing and implanting practical technical changes along value chains, the lack of Climate Finance instruments dedicated to the livestock sector and the lack of cost-efficient MRV systems.

The environmental challenges related to the livestock sector will increase in the coming decades, and it is essential to channel increasing amounts of Climate Finance into the sector to help addressing these bottlenecks and implement mitigation practices. Although some barriers exist, recent developments can facilitate the funding of a low-carbon sector. Both the public and private sectors show engagement toward increasing environmental sustainability and seem to recognize its potential financial benefits in the long term. The development of adequate MRV methods is still lacking, but several tracking and monitoring systems adapted to the specificities of the sector exist and are scalable. The engagement of the whole value chain is probably the most complex barrier, as it must overcome some socio-cultural challenges while aligning the interests of all stakeholders. Finally, the anticipated continued growth of demand for animal protein products will also constitute a tremendous opportunity to invest in new sustainable production systems.

\section{Acknowledgements}

This work is a product of the staff of The World Bank with external contributions. The findings, interpretations and conclusions expressed in this work do not necessarily reflect the views of The World Bank, its Board of Executive Directors or the governments they represent. We thank the reviewers for constructive comments on an earlier version of the paper.

(1) J. Massé 0000-0002-4277-5598

\section{Declaration of interest}

The authors declare no conflicts of interest.

\section{Ethics statement}

Conducting this review involved no animal handling or procedures.

\section{Software and data repository resources}

No new software or original data resources were generated as part of this study. 


\section{References}

Alexandratos N and Bruinsma J 2012. World agriculture towards 2030/2050: the 2012 revision. Food and Agriculture Organization of the United Nations, Rome, Italy.

Avetisyan M, Golub A, Hertel T, Rose S and Henderson B 2011. Why a global carbon policy could have a dramatic impact on the pattern of the worldwide livestock production. Applied Economic Perspectives and Policy 33, 584-605.

Ballesteros A, Nakhooda S, Werksman J and Hurlburt K 2010. Power, responsibility, and accountability: rethinking the legitimacy of institutions for Climate Finance. Climate Law 1, 261-312.

Barona E, Ramankutty N, Hyman G and Coomes OT 2010. The role of pasture and soybean in deforestation of the Brazilian Amazon. Environmental Research Letters 5, 024002.

Blended Finance Taskforce 2018. Better finance, better world. Business \& Sustainable Development Commission, London, UK.

Buchner B, Clark A, Falconer A, Macquarie R, Meattle C and Wetherbee C 2019. Global landscape of Climate Finance 2019. Climate Policy Initiative, London, UK.

Carrefour Foundation 2018. "Zero deforestation" beef meat production in Brazil. Retrieved on 14 November 2019 from http://www.fondation-carrefour. org/content/zero-deforestation-beef-meat-production-brazil

Cencosud 2018. Carta de Compromisso: Compra Sustentável de crane 2018. Retrieved on 17 November 2019 from https://www.oeco.org.br/wp-content/ uploads/2019/02/Carta-de-compromisso-carne.pdf

Clean Development Mechanism 2019. CDM methodology booklet, 11th edition. UNFCCC, Geneva, Switzerland

De Sy V, Herold M, Achard F, Beuchle R, Clevers JGPW, Lindquist E and Verchot L 2015. Land use patterns and related carbon losses following deforestation in South America. Environmental Research Letters 10, 124004.

Dulal HB and Brodnig G 2010. Social and institutional barriers to climate change mitigation in agriculture world bank other operational studies 11093 . The World Bank, Washington, DC, USA.

Falconer A and Stadelmann M 2014. What is Climate Finance? Definitions to improve tracking and scale up Climate Finance. Climate Policy Initiative (CPI), San Francisco, CA, USA.

FAO 2018. The future of food and agriculture - Alternative pathways to 2050. FAO, Rome, Italy.

Food and Agriculture Organization of the United Nations 2014. The state of food and agriculture 2014: innovation in family farming. FAO, Rome, Italy.

Galaz V, Crona B, Dauriach A, Scholtens B and Steffen W 2018. Finance and the Earth system - Exploring the links between financial actors and non-linear changes in the climate system. Global Environmental Change 53, 296-302.

Gerber PJ, Hristov AN, Henderson B, Makkar H, Oh J, Lee C, Meinen R 2013. Technical options for the mitigation of direct methane and nitrous oxide emissions from livestock: a review. Animal 7(suppl. 2), 220-234.

Gerber PJ, Steinfeld H, Henderson B, Mottet A, Opio C, Dijkman J, Falcucci A and Tempio G 2013. Tackling climate change through livestock - A global assessment of emissions and mitigation opportunities. Food and Agriculture Organization of the United Nations (FAO), Rome, Italy.

Global Impact Investing Network 2018. A resource for structuring blended finance vehicles. The Global Impact Investing Network, New York, NY, USA.

Global Roundtable for Sustainable Beef (GRSB) 2018. 2018 Sustainability report. GRSB, Colorado Springs, CO, USA.

Hamrick K and Gallant M 2017. Unlocking potential: state of the voluntary carbon markets 2017. Forest Trends' Ecosystem Marketplace, Washington, DC, USA.

Hamrick K and Gallant M 2018. Voluntary carbon markets insights: 2018 outlook and first-quarter trends. Forest Trends' Ecosystem Marketplace, Washington, DC, USA.

Henderson B, Golub A, Pambudi D, Hertel T, Godde C, Herrero M, Cacho 0 and Gerber $P$ 2018. The power and pain of market-based carbon policies: a global application to greenhouse gases from ruminant livestock production. Mitigation and Adaptation Strategies for Global Change 23, 349-369.

Herrero M, Thornton PK, Gerber P and Reid RS 2009. Livestock, livelihoods and the environment: understanding the trade-offs. Current Opinion in Environmental Sustainability 1, 111-120.
Herrero M, Thornton PK, Kruskaa R and Reida S 2008. Systems dynamics and the spatial distribution of methane emissions from African domestic ruminants to 2030. Agriculture, Ecosystems \& Environment 126, 122-137.

Joint Implementation (JI) 2020. Jl: Jl projects. Retrieved on 7 November 2019 from https://ji.unfccc.int/JI_Projects/Projectlnfo.html

Marfrig Global Food S.A. 2018 Marfrig 2017 sustainability report. Marfrig Global Food S.A., Sao Paolo, Brazil.

Marke A and Sylvester B 2018. Decoding the current global climate finance architecture. In Transforming climate finance and green investment with blockchains (ed. A Marke), pp. 35-59. Academic Press, Cambridge, MA, USA.

Masson-Delmotte V, Zhai P, Pörtner HO, Roberts D, Skea J, Shukla PR, Pirani A, Moufouma-Okia W, Péan C, Pidcock R, Connors $S$, Matthews JBR, Chen $Y$, Zhou X, Gomis Ml, Lonnoy E, Maycock T, Tignor M and Waterfield T 2018. Intergovernmental Panel on Climate Change 2018. Summary for policymakers. In Global Warming of $1.5^{\circ} \mathrm{C}$. An IPCC special report on the impacts of global warming of $1.5^{\circ} \mathrm{C}$ above pre-industrial levels and related global greenhouse gas emission pathways, in the context of strengthening the global response to the threat of climate change, sustainable development, and efforts to eradicate poverty, pp. 3-24. World Meteorological Organization, Geneva, Switzerland.

McDonald's 2019. Beef sustainability. Retrieved 14 November 2019 from https:// corporate.mcdonalds.com/corpmcd/scale-for-good/beef-sustainability.html

Minerva S.A. 2016. Sustainability Report 2016. Minerva S.A., Sao Paolo, Brazil. Mottet A, Henderson B, Opio C, Falcucci A, Tempio G, Silvestri S, Chesterman S and Gerber PJ 2017. Climate change mitigation and productivity gains in livestock supply chains: insights from regional case studies. Regional Environmental Change 17, 129-141.

Mtimet N and Dube S 2018. International conference on livestock value chain finance and access to credit. In Proceedings book from the livestock finance conference from the livestock finance conference, 21-23 February 2017, Ezulwini, Swaziland.

Nakhooda S, Calland R, Watson C and Van Rooij J 2012. Climate Finance: Readiness preliminary approach and insights from efforts in Southern Africa, Published online by UNFCCC.

Ninomiya Y 2012. Classification of MRV of Greenhouse Gas (GHG) emissions/ reductions: for the discussions on NAMAs and MRV. Policy Brief 25. Institute for Global Environmental Strategies, Hayama, Japan.

Rode J, Pinzon A, Stabile MCC, Pirker J, Bauch S, Iribarrem A, Sammon P, Llerena CA, Muniz Alves L, Orihuela CE, Wittmer H 2019. Why 'blended finance' could help transitions to sustainable landscapes: Lessons from the Unlocking Forest Finance project. Ecosystem Services 37.

Sadler MP 2016. Making climate finance work in agriculture. World Bank Group, Washington, DC, USA.

Searchinger T, Waite R, Hanson C and Ranganathan J 2019. Creating a sustainable food future. World Resources Institute, Washington, DC, USA.

Siew RYJ 2015. A review of corporate sustainability reporting tools (SRTs). Journal of Environmental Management 164, 180-195.

Singh N, Finnegan J and Levin K 2016. MRV 101: understanding measurement, reporting, and verification of climate change mitigation. World Resources Institute, Washington, DC, USA.

Stadelmann M, Michaelowa A and Roberts JT 2013. Difficulties in accounting for private finance in international climate policy. Climate Policy 13, 718-737.

Streck C 2011. Ensuring new finance and real emission reduction: a critical review of the additionality concept. Carbon \& Climate Law Review 2, 158-168.

The Green Climate Fund (GCF) 2015. What is Climate Finance readiness. Retrieved on 14 November 2019, from https://www.gcfreadinessprogramme. org/what-climate-finance-readiness

The Sustainable Trade Initiative (IDH) 2019. Fostering private investments into halting the major driver of deforestation in the Amazon. Retrieved on 14 November 2019 from https://www.idhsustainabletrade.com/news/fostering-privateinvestments-into-halting-the-major-driver-of-deforestation-in-the-amazon/

Umemiya C, Koakutsu K, Amellina A, Ono T, Bannai O, Fong WK and Morimoto T 2015. One hundred questions $\&$ answers about MRV in developing countries. Institute for Global Environmental Strategies (IGES), Kanagawa, Japan.

UNFCCC 2008. Report of the Conference of the Parties on its 13th session, 3-15 December 2007, Bali, Indonesia.

UNFCCC 2015. The UNFCCC NAMA Registry, Factsheet 3. 
UNFCCC 2019. Introduction to Climate Finance. Retrieved November 13, 2019 from https://unfccc.int/resource/bigpicture/

United Nations Framework Convention on Climate Change (UNFCCC) 2010. Report of the XVI conference of the parties, 29 November - 10 December 2010, Cancun, Mexico.

United Nations Framework Convention on Climate Change (UNFCCC) 2019 2018 Biennial assessment and overview of climate finance flows technical report.

United Nations, Department of Economic and Social Affairs, Population Division 2019. World population prospects 2019: Highlights. United Nations, New York, NY, USA.

Vandeweerd V, Glemarec $Y$ and Billet S 2015. Readiness for Climate Finance. United Nations Development Program, New York, NY, USA.

Walmart Inc. 2019. 2018 global responsibility report. Walmart Inc., Bentonville, AR, USA.

Warren P 2019. The role of Climate Finance beyond renewables: Demand-side management and carbon capture, usage and storage. Climate Policy 19, 861-877.

Watson C and Schalatek I 2019. The Global Climate Finance Architecture Climate Funds Fundamentals 2. The Climate Finds Update. Heinrich Boell
Stiftung, Washington, DC, USA and Overseas Development Institute, London, UK.

White J 2018. Tracking mitigation in the livestock sector: country experiences. Retrieved on 14 November 2019 from https://ccafs.cgiar.org/blog/trackingmitigation-livestock-sector-country-experiences

Wilkes A, Reisinger A, Wollenberg E and van Dijk S 2017. Measurement, reporting and verification of livestock GHG emissions by developing countries in the UNFCCC: current practices and opportunities for improvement. CCAFS Report No. 17, Wageningen, the Netherlands.

World Bank Group 2014. Business and livelihoods in African livestock: Investments to overcome information gaps. The World Bank Group Washington, DC, USA

World Bank Group 2019a. Introduction to the investing in sustainable livestock guide \& tool. Retrieved on 14 November 2019 from https://olc.worldbank.org/ content/introduction-investing-sustainable-livestock-guide-tool-0

World Bank Group 2019b. State and trends of carbon pricing 2019. World Bank, Washington DC, USA.

World Economic Forum 2019. Meat: The future series. Options for the livestock sector in developing and emerging economies to 2030 and beyond. The World Economic Forum, Geneva, Switzerland. 